\title{
Comparison of essential oils of endemic Salvia dichroantha Stapf collected from Konya
}

\author{
Ayla KAYA *1, Süleyman DOĞU ${ }^{2}$, Muhittin DİNÇ², Mine KÜRKÇÜOĞLU ${ }^{3}$ \\ ${ }^{1}$ Department of Pharmaceutical Botany, Faculty of Pharmacy, Anadolu University, 26470 Eskişehir, Turkey \\ ${ }^{2}$ Department of Biology, Ahmet Keleşoğlu Faculty of Education, Necmettin Erbakan University, 42090 Konya, \\ Turkey \\ ${ }^{3}$ Department of Pharmacognosy, Faculty of Pharmacy, Anadolu University, TR-26470 Eskişehir, Turkey
}

Received: 05 May 2017 - Accepted: 11 June 2017

\begin{abstract}
In the Anatolia folk medicine, Salvia L. (Lamiaceae) species are used by many people in various villages and towns for the therapeutic value of their essential oils. Salvia dichroantha Stapf is an endemic plant of the Irano-Turanian phytogeographic region. Plant materials were collected during the flowering period from Konya Cihanbeyli $(900 \mathrm{~m})$ and Konya Taşkent $(1800 \mathrm{~m})$. In this study, water-distilled essential oil of Salvia dichroantha was analyzed. The analysis was performed by using a gas chromatography (GC-FID) and gas chromatographymass spectrometry (GC-MS) systems, simultaneously. Eight compounds were identified from the oil of Taşkent representing $96.2 \%$ of the total oil and nine compounds were identified from the oil of Cihanbeyli representing $98.3 \%$ of the total oil. The major components were found as caryophyllene oxide (38.6\%), caryophyllenol I (16.7\%), caryophyllenol II (15.6\%) and caryophylladienol II (11.1\%) for Taşkent; caryophyllene oxide (65.8\%), caryophyllenol II (14.3\%) for the oil of Cihanbeyli.
\end{abstract}

Keywords: Essential oil, GC-FID, GC-MS, Salvia dichroantha

\section{INTRODUCTION}

Lamiaceae family has worldwide distribution and includes over 250 genera and about 7000 species. Also this family is known for its fine herbs like lavender, sage, basil, oregano, thyme, mint, rosemary and is a rich source of essential oils for the perfume and flavoring industry [1]. Lamiaceae is the third largest family in Turkish Flora. The morphologically diverse genus Salvia L. is one of the largest genus of the Lamiaceae family and includes about approximately 1000 species distributed all over the world. Anatolia is a major centre of diversity for the genus Salvia in Asia. The genus was represented by 86 species in the flora of Turkey [2]. Since its publication, some synonyms, some new species and records have been reported with the studies on Salvia species in Turkey. The total number of Salvia species in Turkey has been reached 99 and the ratio of endemism in the genus is approximately $50 \%$ [3, 4].

Salvia species are known as "adaçay1" in Turkey where they grow and consumed as a hot drink. The name salvia, coming from the Latin word for health (salvare or heal). Common sage or garden sage (Salvia officinalis L.) is being an important medicinal and aromatic plant used

*Corresponding Author E-mail: aykaya@anadolu.edu.tr 
in folk medicine for centuries. Earliest times, many species of Salvia use as a tonic, stimulant, carminative, antiseptic, spasmolytic, diuretic, herbal tea, spices, to treat inflammations in the mouth, antihydrotic and flavour food in cosmetics, perfumes and pharmaceutical industries are reported [5]. The plants of this genus are rich in essential oils and among their constituents, 1,8cineol (eucalyptol) and guaiane mono and sesquiterpenes are very common [6].

As well as floral morphology, pollination biology and growth forms, the genus Salvia displays remarkable diversity in secondary compounds (essential oils and the phenolic derivatives) [5]. The secondary metabolites isolated from Salvia species possess a long list of medicinal uses [6]. Some of the essential oils and phenolic compounds of plants belonging to this genus have also shown excellent antimicrobial activity as well as antioxidant capacity and some are used as anticancer agents or have hypoglycemic effect [7-11]. Some members of this genus such as Salvia officinalis L, S. tomentosa Miller and S. triloba L. are of economic importance, since they are used as flavoring agents in perfumery and cosmetics. Many of wild growing Salvia species are also used in traditional medicine of different nations instead of sage or as an adulteration [12].

Salvia dichroantha Stapf is an endemic plant species of the Irano-Turanian phytogeographic region. It grows steppes, clearings in forest, roadsides of central, nort and soust west Anatolia and the flowering time is from July to september. S. dichroantha is a perennial herb. Stems are $25-55 \mathrm{~cm}$ length, ascending-erect, branched above or not. Leaves are simple, oblong to oblong-lanseolate. Verticillasters are 2-6 flowered, Calyx is tubularcampanulate, 5-7 mm and corolla is viole, 10-13 $\mathrm{mm}$ [2]. Prepared infusion from leaves of $S$. dichroantha used to external wound treatment in Niğde region.

Chemical constituents and biological activities of the essential oils of some Salvia species were investigated in Turkey (13-26). According to literature search, water-distilled essential oil of $S$. dichroantha was previously analysed using GC and GC-MS and caryophyllene oxide (22.4\%) was found to be the main components in the oil [19]. In this study, we report chemical constituents of endemic S. dichroantha growing in Konya (Taşkent and Cihanbeyli).

\section{MATERIAL and METHODS}

\subsection{Plant material}

Salvia dichroantha was collected during the flowering period (July, 2009-2013) from Konya (Taşkent and Cihanbeyli) province of Turkey. Voucher specimens are deposited in the Herbarium of the Faculty of Education of Necmettin Erbakan University in Konya, Turkey (NEÜ Herb.).

\subsection{Isolation of essential oil}

The essential oils from air-dried plant materrials were isolated by hydrodistillation for 3 $\mathrm{h}$, using a Clevenger-type apparatus. The obtained oils were dried over anhydrous sodium sulphate and stored at $+4^{\circ} \mathrm{C}$ in the dark until analysed and tested.

\subsection{GC-MS analysis}

The GC-MS analysis was carried out with an Agilent 5975 GC-MSD system. Innowax FSC column ( $60 \mathrm{~m} \times 0.25 \mathrm{~mm}, 0.25 \mu \mathrm{m}$ film thickness) was used with helium as carrier gas $(0.8 \mathrm{ml} / \mathrm{min})$. GC oven temperature was kept at $60^{\circ} \mathrm{C}$ for $10 \mathrm{~min}$ and programmed to $220^{\circ} \mathrm{C}$ at a rate of $4^{\circ} \mathrm{C} / \mathrm{min}$, and kept constant at $220^{\circ} \mathrm{C}$ for $10 \mathrm{~min}$ and then programmed to $240^{\circ} \mathrm{C}$ at a rate of $1^{\circ} \mathrm{C} / \mathrm{min}$. Split ratio was adjusted at $40: 1$. The injector temperature was set at $250^{\circ} \mathrm{C}$. Mass spectra were recorded at $70 \mathrm{eV}$. Mass range was from $\mathrm{m} / z, 35$ to 450 . 


\subsection{GC analysis}

The GC analysis was carried out using an Agilent 6890N GC system. FID detector temperature was $300^{\circ} \mathrm{C}$. To obtain the same elution order with GC-MS, simultaneous autoinjection was done on a duplicate of the same column applying the same operational conditions. Relative percentage amounts of the separated compounds were calculated from FID chromatograms. The analysis results are given in Table 1.

\subsection{Identification of components}

Identification of the essential oil components were carried out by comparison of their relative retention times with those of authentic samples or by comparison of their relative retention index (RRI) to series of $n$-alkanes. Computer matching against commercial (Wiley GC/MS Library, Adams Library, MassFinder 3 Library [27,28] and in-house "Başer Library of Essential Oil Constituents" built up by genuine compounds and components of known oils, as well as MS literature data $[29,30]$ was used for the identification.

\section{RESULTS and DISCUSSIONS}

The essential oils of the aerial parts of $S$. dichroantha collected from Konya Taşkent and Cihanbeyli were obtained by hydrodistillation, in $0.01 \%$ and $0.02(\mathrm{w} / \mathrm{w})$ oil yields respectively. The essential oils of plants were analysed by GC-FID and GC-MS. Taşkent samples were collected from $1800 \mathrm{~m}$ while Cihanbeyli samples were collected from $900 \mathrm{~m}$. The compounds identified from the essential oils along with their relative percentages are listed in Table 1. A total of 8 and 9 compounds were identified from the essential oils of Taşkent and Cihanbeyli, respectively, which represented 96.2 and $98.3 \%$ of the oils. Components of the oils can be grouped into two (Taşkent) or three (Cihanbeyli) main chemical classes, sesquiterpene hydrocarbones, oxygenated sesquiterpenes and diterpenes. The oil isolated from taşkent was dominated by oxygenated sesquiterpenes (92.6\%), caryophyllene oxide $(38.6 \%)$, caryophyllenol I (16.7\%), caryophyllenol II (15.6\%) and caryophylladienol II (11.1\%) being the main compounds. The oil of cihanbeyli was characterized by a high content of oxygenated sesquiterpenes $(95.1 \%)$, caryophyllene oxide $(65.8 \%)$, caryophyllenol II $(14.3 \%)$ were found as the main compounds.

According to Table 1, oxygenated sesquiterpenes are present in almost equal amounts in the oils of Taşkent and Cihanbeyli. However, diterpenes in the oil of Taşkent are more than oil of Cihanbeyli and sesquiterpene hydrocarbons in oil of Taşkent is absent. The essential oil composition of sixty-four Salvia taxa from Turkey has already been studied [25]. Monoterpene hydrocarbones (1) ( $\alpha / \beta$-Pinene), oxygenated monoterpenes (2) (1,8-cineole/camphor, linalyl acetate/linalool, carvacrol), sesquiterpene hydrocarbons (3) ( $\beta$-caryophyllene, germacrene D), oxygenated sesquiterpenes (4) (spathulenol) and (5) phenylpropanoid (methylchavicol) reported as the main groups of constituents in Salvia oils. According to our results, $S$. dichroantha had many oxygenated sesquiterpenes. So this plant could be categorized in fourth. In another our studies, sesquiterpene hydrocarbones and oxygenated sesquiterpenes were dominated in the essential oil isolated from S. viscosa Jacq. [26] and Salvia glutinosa L. [22], and caryophyllene oxide were found as the main compounds.

Russo et al. (2016) studied essential oils of Salvia aurea L., Salvia judaica Boiss. and Salvia viscosa Jacq. and they reported all rich in sesquiterpenes, particularly oxygenated sesquiterpenes, with caryophyllene oxide as main compound for all three oils [7]. Comparing our results on $S$. dichroantha essential oil with those previously reported, we can see that they notably same.

According to literature survey, there is only one study on the essential oil from aerial parts of $S$. dichroantha collected from Bilecik in 2011 reported by Kunduhoğlu et al. The essential 
oil obtained by hydrodistillation using Clevenger type apparatus and caryophyllene oxide $(22 \%)$ was found as majör compounds [19]. According to our results, Konya samples were found to be richer in caryophyllene oxide (38.6\%-Taşkent and $65.8 \%$-Cihanbeyli), than the Bilecik sample.

Table 1.The compositions of the essential oils of S. dichroantha.

\begin{tabular}{|c|c|c|c|}
\hline RRI & Compounds & Taşkent & Cihanbeyli \\
\hline 1612 & $\beta$-Caryophyllene & - & 1.9 \\
\hline 1882 & 1-Isobutyl 4-isopropyl-2,2-dimethyl succinate & 1.2 & - \\
\hline 2008 & Caryophyllene oxide & 38.6 & 65.8 \\
\hline 2050 & (E)-Nerolidol & - & 0.5 \\
\hline 2071 & Humulene epoxide-II & 1.9 & 2.7 \\
\hline 2131 & Hexahydrofarnesyl acetone & - & 1.3 \\
\hline 2144 & Spathulenol & 8.7 & 3.4 \\
\hline 2205 & Clovenol & 2.6 & - \\
\hline 2324 & $\begin{array}{l}\text { Caryophylladienol II } \\
\text { (=caryophylla-2(12),6(13)-dien-5 } \alpha-o l)\end{array}$ & 11.1 & 3.6 \\
\hline 2353 & $\begin{array}{l}\text { Caryophyllenol I } \\
\text { (=Caryophylla-2(12),6-dien-5 } \alpha \text {-ol) }\end{array}$ & 16.7 & 4.8 \\
\hline \multirow[t]{4}{*}{2392} & 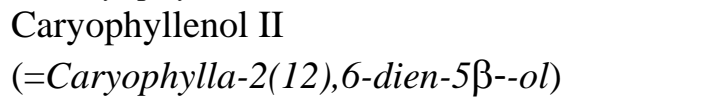 & 15.6 & 14.3 \\
\hline & Sesquiterpene hydrocarbones & - & 1.9 \\
\hline & Oxygenated sesquiterpenes Diterpenes & $\begin{array}{c}92.6 \\
3.6\end{array}$ & $\begin{array}{c}95.1 \\
1.3\end{array}$ \\
\hline & Total & 96.2 & 98.3 \\
\hline
\end{tabular}

RRI; Relative retention indices calculated against n-alkanes C8-C30. \%; calculated from the FID chromatograms tr; Trace $(<0.1 \%)$

Various factors, both endogenous and exogenous, can affect the composition of the essential oil of S. dichroantha. We believe that the time of flowering, altitude, geographical and climatic factors may be very important. Several papers have reported on the variation in the essential oil composition induced by environmental, physiological and edaphic factors which can induce changes in biosynthesis accumulation or metabolism of given compounds of the essential oil [24].

\section{CONCLUSION}

Water-distilled essential oil of $S$. dichroantha was analyzed. The analysis was performed by using GC-FID and GC-MS systems, simultaneously. Eight compounds were identified from the oil of Taşkent representing $96.2 \%$ of the total oil and nine compounds were identified from the oil of Cihanbeyli representing $98.3 \%$ of the total oil. The major components were found as caryophyllene oxide (38.6\%), caryophyllenol I (16.7\%), caryophyllenol II (15.6\%) and caryophylladienol II (11.1\%) for Taşkent; caryophyllene oxide (65.8\%), caryophyllenol II (14.3 $\%)$ for the oil of Cihanbeyli.

\section{Conflict of Interests}

Authors declare that there is no conflict of interests. 


\section{REFERENCES}

[1]. Harley, R. M., Atkins, S., Budantsey, A. L., Cantino, P. D., Conn, B. J., Grayer, R., Kok, R. de, Krestovskaja, T., Morales, R., \& Paton, A. J. (2004). Labiatae. In: The families and genera of vascular plants. Edit., J.W. Kadereit, Vol. 7. pp. 167-275. Berlin Heidelberg: Springer.

[2]. Hedge, I.C. (1982). Salvia L. In: Flora of Turkey and the East Aegean Islands, Edit., P.H. Davis, Vol. 7. pp. 400-461. Edinburgh: Edinburgh University Press.

[3]. Kahraman, A., Doğan, M., \& Celep, F. (2011). Salvia siirtica sp. nov. (Lamiaceae) from Turkey. Nordic Journal of Botany, 29, 397-401.

[4]. Kahraman, A., Bagherpour, S., Karabacak, E., Doğan, M., Doğan, H.,M., Uysal, İ., \& Celep, F. (2012). Reassessment of conservation status of Salvia L. (Lamiaceae) in Turkey II. Turkish Journal of Botany, 36, 103-124.

[5]. Kintzios, S. E. (2000). Sage: the genus Salvia, Australia, Canada: .Harwood academic Publisher.

[6]. Ahmadi, L., \& Mirza, M. (1999). Essential oil of Salvia multicaulis Vahl. from Iran. Journal of Essential Oil Research, 11, 289-290.

[7]. Russo, A., Formisano, C., Rigano, D., Cardile, V., Arnold, N. A., \& Senatore, F. (2016). Comparative phytochemical profile and antiproliferative activity on human melanoma cells of essential oils of three lebanese Salvia species. Industrial Crops and Products, 83, 492-499.

[8]. Miladinovic, D., \& Miladinovic, L. (2000). Antimicrobial activity of essential oil of sage from Serbia. Facta Universitatis, Series. Physics, Chemistry and Technology, 2, 97-100.

[9] . Tepe, B., Daferara, D., Sökmen, A., Sökmen, M., \& Polissiou, M. (2005). Antimicrobial and antioxidant activities of the essential oil and various extracts of Salvia tomentosa Miller (Lamiaceae). Food Chemistry, 90, 333-340.

[10]. Bozin, B., Mimica-Dukic, N., Samojlik, I., \& Jovin, E. (2007). Antimicrobial and antioxidant properties of rosemary and sage (Rosmarinus officinalis L. and Salvia officinalis L., (Lamiaceae) essential oils. Journal of Agricultural and Food Chemistry, 55, 7879-7885.

[11]. Khalil, R., \& Zheng-Guo, L. (2011). Antimicrobial activity of essential oil of Salvia officinalis L. collected in Syria. African Journal of Biotechnology, 10, 8397-8402.

[12]. Bisset, N. G., \& Wichtl, M. (2001). Herbal Drugs and Phytopharmaceuticals. Boca Raton, London, New York, Washington D.C., USA: CRC Press.

[13]. Başer, K. H. C., Özek, T. Kırımer, N. \& Tümen, G. (1993). The essential oil from Salvia pomifera L., Journal of Essential Oil Research, 5, 347-348.

[14]. Başer, K. H. C., Beis S. H., \& Özek T. (1995). Composition of the essential oil of Salvia cryptantha Monbret et Aucher ex Benth. from Turkey. Journal of Essential Oil Research, 7, 113-114.

[15]. Başer, K. H. C., Demirçakmak, B., \& Ermin, N. (1996). Essential oil of Salvia syriaca. Journal of Essential Oil Research, 8, 105-106.

[16]. Başer, K. H. C., Duman, H., Vural, M., Adıgüzel, N., \& Aytaç, Z. (1997). Essential oil of Salvia aytacii M. Vural et N. Adıgüzel. Journal of Essential Oil Research, 9, 489-490.

[17]. Başer, K. H. C., Kürkcüoğlu, M., \& Aytaç, Z. (1998). Composition of the essential oil of Salvia euphratica Monbret et Aucher ex Benth. var. euphratica from Turkey. Flavour and Fragrance Journal, 13, 63-64. 
[19]. Demirci, B., Başer, K. H. C., \& Tümen, G. (2002). Composition of the essential oil of Salvia aramiensis Rech. fil. growing in Turkey, Flavour and Fragrance Journal, 17, 23-25.

[19]. Kunduhoglu, B., Kürkcüoğlu, M., Duru, M. E., \& Baser, K. H. C. (2011). Antimicrobial and anticholinesterase activities of the essential oils isolated from Salvia dicroantha Stapf., Salvia verticillata L. subsp. amasiaca (Freyn and Bornm.) Bornm. and Salvia wiedemannii Boiss. Journal of Medicinal Plants Research, 5(29), 6484-6490.

[20]. Demirci, B., Başer, K. H. C., Yıldız, B., \& Bahçecioglu, Z. (2003). Composition of the essential oils of six endemic Salvia Species from Turkey, Flavour and Fragrance Journal, $18,116-121$.

[21]. Kürkçüoğlu, M., Başer, K. H. C., \& Duman, H. (2002). Composition of essential oils from two varieties of Salvia aucheri Bentham growing in Turkey, Journal of Essential Oil Research, 14, 241-242.

[22]. Kaya, A., Demirci, B., \& Başer, K. H. C. (2003). Glandular trichomes and essential oils of Salvia glutinosa L., South African Journal of Botany, 69, 422-427.

[23]. Kaya, A., Başer, K. H. C., \& Demirci, B. (2009). Composition of essential oil of endemic Salvia wiedemannii from Turkey, Chemistry of Natural Compounds, 45, 552-553.

[24]. Senatore, F., Fusco, R., \& Feo, V. (1997). Essential oils from Salvia spp. (Lamiaceae), I. Chemical composition of the essential oils from Salvia glutinosa L. growing wild in southern Italy. Journal of Essential Oil Research, 9, 151-157.

[25]. Başer, K. H. C. (2002). Aromatic biodiversity among the flowering plant taxa of Turkey, Pure and Applied Chemistry, 74(4), 527-545.

[26]. Kaya, A., Dinç, M., Doğu, S., \& Demirci, B. (2017). Compositions of essential oils of Salvia adenophylla, Salvia pilifera, and Salvia viscosa in Turkey. Journal of Essential Oil Research, 29(3), 233-239.

[27]. McLafferty, F.W., \& Stauffer, D. B. (1989). The Wiley/NBS Registry of mass spectral data, J Wiley and Sons. New York.

[28]. Koenig, W. A., Joulain, D., \& Hochmuth, D. H. (2004). Terpenoids and related constituents of essential oils. MassFinder 3. ed. D.H. Hochmuth, Convenient and rapid analysis of GCMS. Hamburg, Germany.

[29]. Joulain, D., \& Koenig, W. A. (1998). The atlas of spectra data of sesquiterpene hydrocarbons, EB-Verlag, Hamburg.

[30]. ESO 2000. (1999). The complete database of essential oils, Boelens aroma chemical information service. The Netherlands. 